\title{
Enterprising and Delivering a Better Quality of Life for All in South Africa: Progress and Prospects
}

\author{
Darma Mahadea \\ School of Accounting, Economics and Finance, University of KwaZulu-Natal \\ Email: Mahadead@ukzn.ac.za
}

\section{Doi:10.5901/mjss.2014.v5n8p187}

\begin{abstract}
Delivering a better quality of life for all is a top goal of policy-makers in South Africa. Since the country has become a democracy in 1994, considerable progress has been made in empowering citizens with opportunities towards a better life and in providing them with education, housing and other social services. The expansion of state services has been facilitated by positive economic growth rates to finance the rising welfare redistributions. However, employment has lagged behind output growth, resulting in high levels of unemployment, income inequality and poverty, though this is partly eased by the social grants from the government. This paper examines the progress, challenges and prospects of delivering a better quality of life in South Africa. The prospects for the state sector to enhance the delivery of a better life through the welfare net are limited, while considerable backlogs in service delivery still exist. Some of the challenges, particularly to enhanced job creation and enterprising are associated with labour legislation, low entrepreneurial capacity and education limitations. Using data on unemployment, entrepreneurship (TEA) and real per capita GDP for the period 2000-2012, preliminary regression results indicate that unemployment is inversely related to the country's TEA rates and growth in real GDP per head impacts significantly on reducing unemployment.
\end{abstract}

Keywords: Economic growth, labour absorption, entrepreneurship, unemployment.

\section{Introduction}

The quest for a better life is a desired goal of virtually all individuals. While many developed countries are registering low economic growth rates amidst financial and fiscal austerities, some developing countries, in particular China, India and Mozambique are experiencing high levels of economic growth. The high-growth countries are able to produce more private and public goods and services, and generate income and employment opportunities, enabling their citizens to enjoy a better quality of life.

In South Africa policy-makers of all persuasions are aiming to improve national prosperity and the well-being of the citizens. Since the demise of apartheid in 1994, South Africa has consistently experienced positive growth rates, up to 5\% per annum during certain years. This performance facilitated the government to embark on various redistributive and welfare projects that impact on improving the quality of life. However, numerous challenges of the economic landscape, partly emanating from global and internal conditions, make it rather difficult for all individuals to experience a simultaneous improvement in life. On the domestic front, high levels of unemployment, poverty and income inequality are impacting adversely on individual welfare. The government has come up with numerous strategies and institutions, ranging from the Reconstruction and Development Program (RDP) and Growth and Redistribution Strategy (GEAR), to the Small Business Development Agency (SBDA) to improve opportunities and living conditions of the disadvantaged people. More recently, following the establishment of the National Planning Commission, a new strategy has emerged, the National Development Plan (NDP). The NDP aims to deliver citizens' prosperity and well-being by making South Africa a winning nation without unemployment or poverty and with reduced inequality by the year 2030 .

This paper examines the progress made by post-apartheid South Africa in delivering its citizens a better quality of life against the background of country's unemployment, economic growth and entrepreneurship situations. It consists of four sections. The first examines South Africa's economic growth and employment performance during the period 19942012. The second covers progress towards creating a better quality of life. The third covers the challenges and prospects to improving citizens' welfare. The last section uses a simple regression analysis to examine the association between the country's level of entrepreneurship, GDP per capita and 'narrow' unemployment during the period 2000-2012, and concludes with some policy suggestions. 


\section{South Africa's Unemployment and Economic Growth Performance: 1994 -2012}

South Africa registered an average growth rate of 3\% over the periods 1994-2003, 2010-2012 and 5\% during the period 2004 to 2007 (Figure 1). Real GDP per capita increased from R28 536 in 1994 to R37476 in 2012 (SARB, March 2013), indicating an improvement in the spending power of the average household. Early years' economic growth responded positively to the stimulus from public sector infrastructure investment, especially in roads, stadia, the Gautrain project and improvements of airports in anticipation of the 2010 Soccer World Cup.

Figure 1: South Africa's Real GDP 1994-2012.

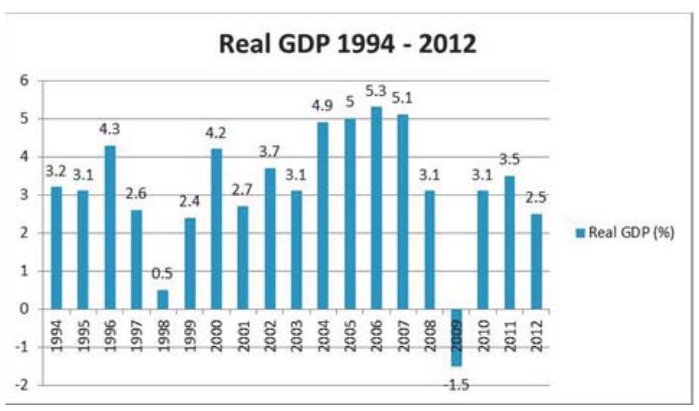

Source: Adapted SARB Quarterly Bulletins,1994-2012 and June 2013.

Despite positive economic growth rates, employment is not increasing sufficiently to absorb all the annual job seekers. Output growth does not guarantee the wellbeing of all people, unless they earn a productive income. This is South Africa's current dilemma.

As we live in an era of heightened materialism, people need to earn an income ethically through value-adding to the national output, to enable them meet their basic needs. Earning an income from remunerative work contributes to human happiness as it enables individuals to create networks with communities, workmates, friends and neighbours. All these contribute to building up social capital (Putman, 2000). However, given South Africa's high unemployment rate at $25 \%$ in 2013 , many individuals are not earning a wage income. If one adds the discouraged worker group, that increased from 1.1 million in 2009 to 2.3 million individuals in March 2013, expanded unemployment is higher, 36.7\% (Stats SA, 2013).

Total employment decreased by 106000 (formal sector $0.3 \%$ and informal sector $0.6 \%$ ) between the second half of 2012 and first quarter of 2013 (SARB, 2013). The job losses in the private sector were offset by gains in the public sector, which expanded its workforce by about 65000 employees in 2012, raising its share of employment to 26\% (SARB, 2013). However, this continued increase in public sector or public works employment is not sustainable for driving long run job creation. There were about 13.6 million individuals employed, 4.6 million jobless, and 15 million South Africans not economically active in 2012 (Stats SA, 2013).

The problem of unemployment is more severe among the youth and women, and in the rural areas; South Africa has one of the highest youth unemployment rates in the world (Holborn, 2011). Youth unemployment increased from 48.1\% in 2009 to 51.6\% in March 2012 (SARB, 2012). Recent figures (May 2013) from Stats SA indicate that more than 3.5 million (33.5\%) young people in the 15-24 age group were not in school or in training and not in employment. As these young individuals are disengaged from both work and training, they can be a source of socially disruptive behavior.

Concerned about delivering a better life, the government has put in place various strategies and institutions to stimulate job creation, combat poverty and grow the economy. These include the RDP, GEAR, National Youth Development Agency (NYDA), Accelerated and Shared Growth Initiative for South Africa (ASGISA), New Growth Path (NGP) and NDP. The NDP is a plan for a better future for all. By drawing on the participation of all South Africans it aims to create a prosperous and inclusive economy, in which nobody should live in poverty or goes hungry and there is work for all, by 2030.

Despite all these initiatives, South Africa's growth and unemployment rates continue to be a development concern. Encouragingly, President Zuma declared 2011 as the "year of job creation", with several initiatives to boost job creation, such as a R9 billion jobs fund and R20 billion in tax allowances to infrastructure investment projects. However, 
increasingly there are signs of disillusionment among individuals because unemployment among the poorer community remains extremely high. After almost 20 years of post-apartheid democracy, many individuals are asking, "where are the promised (decent) jobs?" contributing to a "better life" for all in South Africa. The challenges and prospects of delivering a 'better life for all' in South Africa can be examined by looking at the recent trends in the country's GDP-employment ratio. This is considered below.

\subsection{The GDP-employment ratio}

The relation of unemployment with GDP can be assessed by linking the change in GDP to the change in employment. South Africa's growth performance in relation to employment has been mixed, labor displacing and absorbing in certain years. Labor displacement relative to the country's GDP appears to have been at -1.6 in 2001 (Table 1). For the years 2001 and 2010, South Africa seems to have experienced a situation of jobless growth, negative growth in 2009, but labor absorption was positive in the other years, reflecting no evidence of a persistent jobless growth scenario. Output expansion with a less than proportionate increase in the labour force may reflect an increase in capital input and total factor productivity. Indeed, the average capital-labour ratio increased from R166 016 in 2000 to R195501 in 2012, reflecting rising capital intensity in production (SARB, March 2013). A pertinent question is why a low employment growth rate in South Africa.

Research by Haroon Bhorat and Nir Klein, economists from UCT and IMF respectively, shows that there is a weak link between wages in South Africa and productivity, and this holds back growth and job creation (Bisseker, 2012). They argue that central bargaining confers a wage premium of about $20 \%$ to the unionised public sector workers and add about $10 \%$ to the average nonunionized private sector worker. Another research, using regression analysis, covering the period 1994-2010, indicates that the marginal impact of economic growth on employment is positive and significant (beta coefficient at 0.8401 and its associated t-value at 3.89 , a constant of -2.6770 , with an associated t-value -3.41$)$. But taking the influence of other exogenous factors into account, when growth rises by one per cent, the marginal employment effect falls by more than $0.84 \%$ (Mahadea and Simson, 2011).

Table 1. Unemployment, Employment Index and GDP/Employment Ratio: 2000-2012

\begin{tabular}{ccccc}
\hline Year & Unemployment Rate \% & Labor Employment Index & Change & Ratio GDP growth to Employment Growth \\
\hline 2000 & 25.4 & 100 & - & - \\
2001 & 29.4 & 98.4 & -1.6 & -1.68 \\
2002 & 30.4 & 117.8 & 19.4 & 0.190 \\
2003 & 28.2 & 135.1 & 17.3 & 0.179 \\
2004 & 26.2 & 140.7 & 5.6 & 0.875 \\
2005 & 26.7 & 150.2 & 9.5 & 0.526 \\
2006 & 25.5 & 167.1 & 16.9 & 0.313 \\
2007 & 24.3 & 175.8 & 8.7 & 0.586 \\
2008 & 22.9 & 179 & 3.2 & 0.968 \\
2009 & 24.0 & 173.6 & -5.4 & -0.278 \\
2010 & 23.3 & 172.3 & -1.3 & -1.15 \\
2011 & 25.0 & 176 & 3.7 & 0.95 \\
2012 & 25.1 & 178.2 & 2.2 & 1.14 \\
\hline
\end{tabular}

Source: SARB Quarterly Bulletins, 2000-2013 (June), Stats SA Quarterly Labour Force Surveys, Bhorat, 2010.

Further, low employment growth is the result of the interaction of exogenous influences and various demand and supply factors (Bhorat and Mayet, 2013; Barker, 2007; Kingdom and Knight (2004); Loots, 1998). These include:

- modest economic growth,

- production increasingly becoming capital and skill-intensive,

- inflexible labour market characterized by downward rigidities in real wages,

- labour regulations,

- trade union power securing wage increases above inflation rates,

- poor work ethics,

- soaring labour costs,

- taxation and crime,

- Low levels of quality education, skills and entrepreneurship. 
If there is to be prosperity for all, individuals who are able and willing to work must be able to find employment. People have aspirations for a better life in South Africa. For many individuals, these aspirations are unlikely to be realized unless they are absorbed in the mainstream economy. However, a welfare safety net is offered by the state's redistribution in the form of a social wage to improve living conditions among vulnerable households. This is covered in the next section.

\section{Poverty and Social Wage}

Extreme poverty was an issue in 1994. In a low income country poverty is marked by living on $\$ 1.25$ per day. Using this indicator, the proportion of South African population falling below the $\$ 1.25$ mark decreased from $17 \%$ in 2000 to $9.7 \%$ in 2006. $\$ 2$ is the poverty standard in middle income countries, like South Africa; using this standard the prevalence of poverty decreased from 12\% in 1996 to 5\% in 2010 (The Economist, 2012). According to the census 2011, the average annual household income for all households in South Africa more than doubled in the past decade, increasing from R48 385 in 2001 to R103 204 in 2011. South Africa has made great strides in improving the citizens' welfare further through the offer of a 'social wage'.

The social wage is a redistribution of income as a safety net to poor households, in the form of health, education, housing and local amenities. Over $60 \%$ of working people in South Africa earn less than R5, 000 a month. However, over half of all households are able to supplement this low "economic wage" earned from work by a "social wage" offered by the government (Budget Review 2013).

Expenditure on social wage, as a proportion of GDP, has increased from 13\% in 2002 to $19 \%$ (about R600 billion) in 2012/13. The number of state grant beneficiaries has increased from 2.9 million 1993/94 in to 16.5 million in 2012/13, of these child support is over 11million. The child support grants represent about $70 \%$ of the total headcount of social grant beneficiaries (Table 2). The number of child grant beneficiaries has risen from 5.7 million in 2004 to over 11.4 million in 2013 , largely as a result of the broadened access in the eligibility age to a child's 18th birthday. The child support grants absorb over $9 \%$ of the social protection budget, representing an amount of R44.3 billion in the fiscal year 2013/14 (Budget Review, 2013).

Table 2: State Grant Beneficiaries and Monthly Amounts 2012/13

\begin{tabular}{|l|c|c|}
\hline Grant Types & Monthly Social Grant Values (Rand) & Number of Recipients \\
\hline Old age & 1200 & $2,851,000$ \\
\hline Disability & 1200 & $1,179,000$ \\
\hline Foster care & 770 & 529,000 \\
\hline Care dependency & 1200 & 130,000 \\
\hline Child support & 280 & $11,406,000$ \\
\hline Total & & $16,095,000$ \\
\hline
\end{tabular}

Source: Budget Review 2013.

Parents or other caregivers earning less than R2 800 per month are eligible for the child support grant, which pays R280 per month for each child they are looking after. This amount will increase to R290, and the monthly old age and care dependency grant will also increase to R1260 in the fiscal year 2013/14.

\subsection{Housing, Water and Sanitation}

Shelter is a basic need. During the first ten years since coming to power in 1994, the government has built 1.5 million new housing and RDP units, and 1.8 million housing subsidies were awarded (Optima, 2004). Another 1.5 million free homes were constructed during the 2002 -2012/13 periods (Budget Review, 2013). Overall, between 1994 and 2011, the government built over three million homes, providing shelter to over 13 million people (van Niekerk, 2013). Households living in formal dwellings increased from $65.1 \%$ in 1996 to $77.6 \%$ in 2011 (Stats SA, 2012). With progress in housing comes an extension of electricity and water services. Almost 4 million additional people were connected to the national electricity during the period 1994-2004, and further progress has since been made in the provision of these utilities in the spirit of social solidarity. Households earning less than R3500 per month now qualify for a housing subsidy, presently worth R84000. The amount allocated to housing grants for the poor totalled R15 billion in 2010/11, rising to R17.9 billion in 2013/14 (Budget Review, 2013). All these contribute to reducing the cost of living and delivering a better quality of life 
to the citizens.

In 1994 the government inherited huge services backlogs with respect to access to water and sanitation. About 15 million people were without safe water supply and over 20 million were without adequate sanitation services. Since then, the country has made improvements in these areas. According to the 2011 census, South Africa reached universal access to an improved water source with $91 \%$ of its urban citizens having access to water, while in rural areas access increased from $66 \%$ to $79 \%$ from 1990 to 2010 . With regard to sanitation, access increased from $71 \%$ to $79 \%$ during the same period (Stats SA, 2012). Although people have greater access to public utilities, many individuals cannot afford to pay for these services. Between 2006 and 2010, municipal service charges on water, electricity and refuse removal increased, on average, by $16.6 \%$ annually, which is well above inflation rates; and it is likely that electricity tariffs would increase by another 18\% during the next three years (Bisseker, 2012). This may explain the cause for the rising social discontent, electricity thefts and illegal connections.

\subsection{Education}

Although education is critical for building a country's human capital and strengthening its growth potentials, educational opportunities were low for many South Africans before 1994 (Hirschowitz and Orkin, 1997). The Constitution guarantees universal access to basic education. Primary school attendance has increased from $96.7 \%$ in 2002 to $98.6 \%$ in 2009, and literacy rate has increased from $88 \%$ to $91 \%$ during the same period (Stats SA, 2010). The percentage of population in South Africa with no schooling has dropped from 17.9\% in 2001 to $8.6 \%$ in 2011, and the proportion who have a standard 10 and higher education has increased from $29 \%$ to $40 \%$ over the same period (Stats SA, 2012).

Rising access to education helps to narrow income inequalities and reduce poverty. The government spends about a fifth (21\%) of its budget on education. Expenditure on education has increased almost five-fold, from R43bn in financial year 2000/01 to R233bn in 2013/14. Nationally, the number of learners attending no-fee schools has increased from about 5 million (13,912 schools) in 2007 to 8.5 million (20688 schools) in 2012, representing an increase from $42 \%$ to 70\%. Provincially, Limpopo and Eastern Cape have the highest percentage of no-fee learners at $82 \%$ and $92 \%$ respectively.

Further, government has increased funding to assist poor students to obtain tertiary education and vocational training. Under the National Student Financial Aid Scheme, the number of learners who have been assisted with bursaries and loans have increased from 118160 in 2008/09 to 288188 students in 2012/13, and this number is projected to grow to 642269 in 2015/16 (Budget Review, 2013). As part of the government's anti-poverty strategy, almost 9 million school learners are being fed a meal each school day, which cost the taxpayers almost R5bn in 2011/12 (Budget Review, 2013).

\subsection{Health}

Another factor related to a better quality of life is the citizens' health condition. Health presently absorbs $12.5 \%$ of the national 2013/14 budget, representing an absolute amount R 251.3bn. The life expectancy at birth has improved from 57 in 2009 to 60 in 2011, partly due to the government's HIV/Aids and health programmes.

Similarly, the adult mortality rate improved from 46 in 2009 to 40 in 2011, and under 5 mortality rate improved from 62 in to 42 (Budget Review, 2013; HDR, 2011). However, the HIV prevalence rate in 2009 among the youth (15-24 age) was a high $13.6 \%$ for female and $4.5 \%$ for male (HDR, 2011). The 2011 census indicates that about 5.6 million (nearly $11 \%$ ) of South Africans are living with HIV, and even more alarming is that about $20 \%$ of South African women between 15 and 49 years are HIV positive. About 850 people die from Aids every day and there are over 2 million Aids orphans in South Africa, with potentially alarming social consequences (Chaitram, 2013).

There has been some success in reducing the spread of HIV/Aids. An estimated 1.7 million people received antiretroviral medication in 2012. Mother-to-child transmission of HIV, as measured by the number of children born with HIV as a proportion of those exposed to the virus, has fallen from $8.5 \%$ in 2008 to $2.7 \%$ in 2011, contributing to a marked reduction in child mortality (Budget Review, 2013).

About $16 \%$ of South African households are covered by private medical schemes. To make health care more accessible to the general population, regardless of their income level, the government is focusing on introducing a National Health Insurance (NHI) system in the near future. With improved access to health care, worker productivity and employability can increase. However, the financing and logistics of the $\mathrm{NHI}$ infrastructure is still unclear.

In the light of the above, substantial progress has been made in certain areas towards delivering a better quality of life in South Africa. The level of poverty has decreased significantly as fewer people are living on less than $\$ 2$ a day. A 
higher proportion of the population has access to electricity, water, sanitation and housing than before. BEE and affirmative procurements have provided opportunities for many formerly disadvantaged individuals to own businesses, partake in the mainstream economy and enrich themselves, some earning the status of 'Black Diamonds' (Attud, 2011). Individuals feel happier when their real income is increasing and they have access to household durable items, televisions, fridges and cellular phones. The proportion of households who own durable items has increased significantly between 2001 and 2011. Household ownership of a computer increased from 8.5\% to 21\%, television from 53\% to 75\% cellular phone from $32 \%$ to $89 \%$ (Stats SA, 2012). These reflect that the living conditions of many individuals, especially those in a stable employment, have improved significantly since the end of apartheid. However, many are still living in impoverished conditions in informal settlements, without access to proper public utilities. Additionally, there are signs of service delivery failures in many areas, resulting in frequent demonstrations. Protests take place almost every week and often focus on a lack of basic necessities such as water and electricity (The Economist, 2012). This brings us to the question of the prospects of state redistribution programmes for enhanced delivery of a better quality of life for all.

\section{Prospects}

Wealth is produced mainly by the private sector. In exercising its role as a welfare state, the public sector redistributes scarce resources, and consumes progressively more resources as it tries to meet the rising needs of the citizens. Pursuing populist policies may be helpful in winning votes. The important question is whether one can rely on an expanding the developmental state to deliver a better life to all. Certainly the goal of a better life for all is desirable for people to live more fulfilled lives. In the Paretian context, any allocation of resources that can make at least one individual (or group) better off without making anybody worse off is desirable. From a social welfare perspective, the overall quality of life can be improved when there is a redistribution of resources by the government from the taxpayers to the poor, with no adverse consequences. The higher income groups are taxed at higher tax rates than low income earners under a progressive tax system. The government then uses part of the revenue thus collected to provide a greater amount of goods and social services, such as education, health care, housing and state income grants to the needy and poor - the social wage items.

\subsection{Redistribution and Taxation}

Redistribution to deliver a better quality of life is feasible to the extent that we have a high level of sustainable inclusive economic growth that induces employment creation. Although absolute poverty has decreased, as mentioned earlier, the income gap between the poor and rich has widened in the post-apartheid era. South Africa's gini coefficient (with a value close to 0 indicating most equal and close to 1 most unequal) has increased from 0.59 in 1993 to 0.63 in 2009 (The Economist, 2012). According to the National Planning Commission, this coefficient has recently worsened to 0.70 , making South Africa one of most unequal countries in the world, with the widest income inequality differential between the rich and poor. When poor people are not drawn into the mainstream growth process, it demeans their life to marginalisation, reducing them to 'subjects' rather than 'citizens' (Ramphele, 2012). This can be a threat to social stability, considering what happened in Brazil, Egypt, Libya and other northern African countries in recent times.

Transferring resources to the poor has a merit in mitigating poverty. However, it can also have unintended consequences for corruption and creating a dependency syndrome. When people earn an income without any contribution to output and remain unemployed for long, they lose the habit of industry. What needs to be done is to help the recipients escape dependency on the state and seek dignity through self-supporting work and production. Otherwise, they can become unemployable, socially disconnected and vulnerable to social ills and resort to crimes, robberies and drugs (Ramphele, 2012).

Given the low economic growth rates and thin tax payer base, the scope for further welfare benefits to enhance the quality of life of the majority may be limited, unless the growth or employment trajectory improves significantly. The number of welfare beneficiaries is very large in relation to the number of individual or business taxpayers. Although there are 13 million registered taxpayers in South Africa, only about 4.3 million actually pay income tax, as the remaining are below the tax threshold (Lester, 2013).

Further tax increases on the average middle income earner to fund growth in public welfare expenditure may be unreasonable and inequitable. Already taxes and state costs are rising faster than inflation and eat up a huge proportion of an individual's salary. Research by Schussler indicates that when taxes, municipal charges for utilities and rates and other expenses such as medical aid are added, these leave an average employee with just 17\% (R2409) of his gross salary to spend. He adds that "there is an overtaxing of the man in the middle, not just through direct taxation but through 
other kinds of tax paid to gain access to services ... that the state is not proving adequately" (cited by Peacock, in Sunday Times 5/5/2013). However, extracting a marginal tax increase on the super-rich may be acceptable on a normative ground as they can afford it. Additionally, through their altruistic private donations of money to charitable and non-profit organisations that look after the welfare of the disadvantaged, the rich can increase their happiness as well as those of receiving poor members. The marginal significance of a rand given to the poor is worth more than a rand taken from the wealthy. Accordingly, a rand gain in utility is worth more to the poor person than a Rand loss in utility to the super-rich.

The imposition of higher levels of taxation can adversely affect employees' motivation to work hard and entrepreneurs' risk-taking spirit. This would undermine productivity or enterprise growth, and possibly causing a brain drain, as individuals and entrepreneurs may move their capital and factories to other regions where the tax rate is lower and they feel safer and better rewarded for their labour and entrepreneurial talents. Those who create wealth should not be deprived of the fruits of their labour productivity, whereas beneficiaries of state grants who become consumers of taxpayers' wealth should be encouraged to take pride in developing their own need achievement motivation with lifelong learning and be discouraged from a permanent culture of state dependency. To a grant beneficiary, staying unemployed and collecting a social wage may become a preferred alternative to wage employment, with marginal income gains.

\subsection{Quality of life and Corruption}

Quality of life and subjective well-being are based not only on absolute income but also on relative income (Mahadea, 2013; Posel and Casale, 2011). People compare their income with those of others in the reference group. When the unemployed or low income earners compare their life style with the opulent life style of their neighbour perhaps working in the public sector, there can be a sense of frustration and envy. This may be a motivation for some people in private employment to work harder and earn more income to improve one's quality of life. But among those with low motivation and poor prospects of employment, crime becomes an avenue for obtaining resources for survival. Already, over a third of the of country's prison population is in the youth under 25 age group (Holborn, 2011). Criminal behaviour destroys the moral fabric in a community and wanes investor confidence among local and foreign captains of industry.

As the state is an important procurer of resources, many insiders use their positions in the government to secure state contracts, thus creating a class of 'tenderpreneurs'. South Africa has frequent social protests against incompetence and corruption at various levels of the public sector (Mbeki, 2011:13). Corruption is costing the South African economy dearly (The Economist, 2012). Research indicates that corruption is an impediment to good governance and inhibits economic growth, much needed for enhanced delivery of well-being (Todaro and Smith, 2012). According to the Special Investigating Unit, between 20 and $25 \%$ of state procurement expenditure, amounting to approximately R30 billion is lost annually to overpayment or theft by corrupt state employees (Ramphele, 2012). The Social Services Agency identified 79416 public servants who stole social grants in 2011 (Saunderson-Mayer, 2013). Without corrective measures being taken, the yawning income gap may become even wider. This is more so when there is a lack of accountability or consequences for public servants abusing state resources and when there is a tolerance of this corrupt behaviour. "An increasing number of public servants, who have been accused and in many cases been found guilty of wrong-doing for their disregard of proper public conduct and accountability, are being rewarded with senior posts" (Ramphele, 2012: 127).

According to auditor general's reports a culture of impunity has taken root among many municipalities; there is "grave concern" at high levels of noncompliance and disregard for laws relating to supply chain management, although the government pays, on average, 43\% higher wages than the private sector (Lund, 2012). A (July 2012) report revealed that about half of the lucrative contracts awarded by 284 municipalities in South Africa were given to their employees, local politicians or their families (Gules, 2012). Only 13 municipalities achieved a clean audit, while 156 out of 343 (45\%) obtained unqualified audit reports for 2010/2011. Irregular expenditures at the municipalities increased from R3.2bn in $2008 / 09$ to R10bn in 2010/2011. This situation partly indicates how rate payers' and tax payers' money are being squandered or irregularly spent by public officials, when there is no accountability and when transgressions are not penalised (Bisseker, 2013).

\subsection{Schooling and Training}

Although the matric pass rate has apparently improved over the years, South Africa's quality of education, especially in maths and science, is perceived as low. To raise employment, the country needs better education. According to the World Economic Forum's (WEF) Global Competitiveness Report 2012-2013, South Africa ranks 132 ${ }^{\text {nd }}$ out of 144 countries for its primary education and $143^{\text {rd }}$ for the quality of its maths and science. This underperformance is rather depressing, considering that education absorbs over a fifth of the government's budget. Poor people regard education as 
the gateway to a better life and employment opportunities. Despite of lowering standards to a $30 \%$ or $40 \%$ in certain subjects, the matric pass rates in 2011 and 2012 appeared to have improved from 70.2\% in 2011 to $73.9 \%$ in 2012 . However, when one takes into consideration that only 378466 learners passed matric in 2012 out of a cohort of 1150637 who started school in grade 1, the effective pass rate becomes only $32.9 \%$, marginally lower than the 2011 pass rate (33\%). This effectively implies a dropout rate of $51 \%$ by the time learners reach grade 12 (Jones, 2013). In addition, many girls as young as ten years drop out of school because of pregnancy. Teenage pregnancy and HIV prevalence among the 10-14 age group increased from 7.3\% in 2008 to 9.1\% in 2010 (Ramphele, 2012). In 2011, some 94000 schoolgirls became pregnant, giving them access to child grants (Redelinghuys, 2013).

While quality and performance are better in private schools, there is no guarantee that all school leavers might end up in employment, partly owing to affirmative actions. According to the recruitment agency Adcorp, only about $17 \%$ of matriculates are likely to get employment within a year of leaving school, and although numerous vacancies for suitable candidates exist in the private sector, over half a million university graduates are without employment (The Economist, 2012). As the quality of matric passes does not sufficiently prepare students for university studies, many also drop out after the first year of tertiary education, and others take much longer than three years to successfully complete their first degree. While improving the education performance is critical to the post-apartheid born free individuals' welfare, attending to other economic constraints, such as improving governance and investment, as also mentioned in the NDP, are necessary for a better life for all. Inefficiencies in the private sector are usually eliminated by competition among firms and do not seem to impact on the public sector. However, public sector inefficiencies tend to impact adversely on private sector performance, increasing the transaction costs of doing business and constitute a drain on taxpayers' and investors' confidence. An important question is whether entrepreneurship can make a difference to South Africa's low employmentgrowth trap and improve quality of life. This is examined in the following section.

\section{Entrepreneurship}

Entrepreneurship is an engine of growth, innovation and development in developed and developing countries (Deakins and Freel, 2012; Urban, 2012). Accordingly, entrepreneurship, through the creation and expansion of SMMEs, holds the prospects of creating jobs and augmenting real GDP per capita in South Africa, through which citizens can enjoy a better life. SMMEs already contribute 55\% of total employment in South Africa (Budget Review, 2013), and 45\% to the country's GDP (Herrington, 2012). Clem Sunter argues that an "entrepreneurial revolution", the consolidation of existing formal and informal ventures and the stimulation of a new class of 'foxy' entrepreneurs, is necessary for viable and lasting enterprises, through which millions of sustainable jobs can be created (Sunter, 2010: 128).

According to the Global Entrepreneurship Monitor (GEM) reports, South Africa's entrepreneurial capacity seems to be rather weak for its level development relative to other efficiency-driven countries. Its early stage total entrepreneurial activity rate (TEA) was at 9.4 in 2001, 9.1 in 2011 and still lower, 7\% in 2012 (Herrington, 2012; Parsons, 2013). The average TEA rate for 2001-2005 was 6.14, and 6.6 for 2006-2010. The problem of low entrepreneurship in South Africa is related to education and training, access to finance, cultural and social norms, and government regulations (Herrington, 2011; 2012).

\subsection{Regression}

Using SPSS for a simple exploratory regression analysis, the relationship between real per capita GDP, as the independent variable, and unemployment rate, as the dependent factor, for the period 1994-2012 was examined initially. The initial overall regression ( $F$-value 0.432 ) was not significant. As there could be a problem of endogeneity, unemployment was even considered as an independent factor. Even with data transformations, the regression was still not significant, possibly because of omission of important variables and too short the data period.

As the TEA (entrepreneurship) data for South Africa is available from the year 2000 onwards, the TEA rates and real GDP per head (RGDPH), lagged by one period, for the period 2000-2012 were used as independent variables, with a residual error term (e), and 'narrow' unemployment rates $(U)$ as the response factor in another exploratory regression model, as below.

$$
\mathrm{U}=\mathrm{a}-\mathrm{b} 1 \mathrm{RGDPH}-\mathrm{b} 2 \mathrm{TEA}+\mathrm{e}
$$

A negative correlation $(r=-0.426 ; p=0.150)$ was found to exist between unemployment and TEA. Similarly a positive correlation was found between TEA and GDP per head ( $r=0.304, p=0.363$ ), evidencing no problem of multicollinearity (Field, 2009). An increase in the TEA rate is deemed to impact on reducing unemployment, but this relationship is not sufficiently strong to be considered as a significant predictor $(b 2=-0.2669 ; p=0.326)$. However, the 
regression results show that real GDP per capita is a significant predictor of unemployment, with an overall significant Fvalue at 10.094, an adjusted $R$-square of $0.623 ; b 1=-0.0006 ; t=-3.828 ; p=0.004$. This seems to indicate that with a one per cent rise in per capita real GDP, on average unemployment rate tends to decrease by about $0.06 \%$, other factors assuming to remain constant. However, owing to the limited time period $(n=12)$ and variable constraints, the regression results are to be treated with caution and limitations of the study kept in perspective. As this is only an exploratory analysis, a further study will be undertaken using additional variables and longer time data.

\subsection{Discussion}

As an economy experiences positive economic growth rates that exceed its population growth, real GDP per head increases. As real GDP per capita improves, consumption and aggregate demand increase, which in turn can create more employment opportunities. Beyond a threshold per capita income (about US \$20000) globally across GEM countries, the rate of entrepreneurship and self-employment increases as real GDP improves (Naude, 2012; Herrington, 2011; Acs, 2006). Therefore, with higher rates of economic growth in South Africa and the benefits of effective practice of higher levels of entrepreneurship, real GDP per head and employment rates are likely to increase; consequently making a dent in the appalling unemployment. As Naude (2012: 108) puts it, "for employment creating growth the best type of entrepreneurship is productive, "high potential' entrepreneurship", arising from individuals having high entrepreneurial ability and business growth motivations.

From the above, it appears that there is a tentative case for arguing that un/employment and real per capita GDP are closely related. It is the progress of economic growth and spirit of entrepreneurship that bring labour and capital together to create employment and output opportunities that in turn generate income growth. Growth in real disposable income enables households to buy more goods and services and enhance their utility or subjective happiness. Increased earning power with an improved entrepreneurship rate enhances life satisfaction (Putman, 2000).

If South Africa had a higher rate of SMME entrepreneurial activity as other emerging economies like Brazil and Mexico, (that had a TEA rate of $15 \%$ in 2012), its labour absorption would be increased, thereby significantly decreasing unemployment (Herrington, 2012). According to an Adcorp economist, Loane Sharpe, about 250000 individuals were starting their own enterprises in 2001, but this figure dropped to 58000 in 2011 (Duncan, 2012). It seems something is 'wrong' with the environmental conditions in South Africa, as the SMME sector is struggling and not expanding fast enough. A macroeconomic environment that is generally friendly to business can generate more job opportunities and growth in the economy. But in South Africa, stringent labour legislation set against a background of an abundant pool of unskilled labour is considered to be prohibitive by entrepreneurs. Rautenbach (2010) argues that unionisation and enforcement of over-reaching labour rights, without regard to productivity, make labour expensive and are job-destroying. Accordingly, firms tend to use more capital than labour, and resort to labour brokers and sub-contractors for employment needs.

If firing of non-performing labour is difficult, firms do not hire so easily. Many SMEs are reluctant to employ new staff because of the fear and costly implications of the Commission for Conciliation, Mediation and Arbitration (CCMA), a system in which the employer often ends up paying the employee compensation for riddance (Wijnberg, 2013).

Research by Sage indicates that South African SMME entrepreneurs are dissatisfied with the role the government plays in their business. They found labour laws and tender procedures too burdensome and would like to see government reducing bureaucracy and regulations, lowering taxation and improving education (Duncan, 2012). Confirming earlier findings, the 2012-2013 Global Competitive Report indicated that the five top problematic factors for doing business in South Africa are inadequately educated workforce, restrictive labour regulations, inefficient government bureaucracy, inadequate supply of infrastructure and corruption. On institutions, one of the twelve pillars underpinning the global competitiveness index, business costs of crime and violence in South Africa ranked 134th (out of 144 countries), burden of government regulation ranked $123^{\text {rd }}$ and favouritism in decisions of government officials at $110^{\text {th }}$. In its survey, the SBP SME Growth Index of 2012, an overwhelming 74\% of firms indicated that running an SME had become harder now than before, and over $25 \%$ cited rising input costs, such as electricity prices, municipal rates and services, as major inhibiting growth constraints. Adding the recent higher electricity rates and proposed new Business Licensing legislation for small ventures would impose further bureaucratic burdens on already struggling micro entrepreneurs. Taken together, these findings suggest that it is imperative to simplify regulations, ease the tax burden and combat crime so that entrepreneurship can flourish and more businesses can start up and expand to create output, income and employment opportunities, thus contributing to a safer environment and a better life. 


\section{Conclusion}

In nearly 20 years since South Africa has become a democracy, considerable progress has been made with regard to empowering citizens with access to education, housing, electricity and other public utilities. The expansion of state services has been facilitated by positive economic growth rates that in turn generated enough tax revenue to finance the rising welfare redistributions. But employment has lagged behind output growth, resulting in high levels of unemployment, income inequality and poverty, though partly mitigated by social grants.

Sustaining job creation and enhancing the delivery of a better quality of life purely through the state welfare net is limited. This is largely because of resource limitations. Financing the public sector wage bill, that has already increased by $100 \%$ during the last five years, is extremely onerous on taxpayers, and perhaps unsustainable in the absence of significant productivity gains. The number of income taxpayers is small in relation to the number of state grant beneficiaries. South Africa's sovereign credit rating was recently downgraded. South Africa still may run higher budget deficits financed by debt, as its outstanding external or gross debt gross is relatively low (at about $40 \%$ of the country's 2012 GDP) compared to Greece and Italy. However, rising debt to finance budget deficits would have inflationary and crowding out effects, as well as intergenerational debt servicing cost implications, imposing higher burdens on current and future taxpayers, as well as the country's balance of payments deficits. Many current taxpayers and small businesspersons are apparently already overburdened financially; household debt as a proportion of disposable income is presently at a high 75\%, gross saving by the household sector as a proportion of GDP is a low $1.7 \%$, and real gross fixed capital formation is below 6\% (SARB, June 2013). People in South Africa have been experiencing, on average, a reduced level of life satisfaction in recent years; the perceived well-being score (10 is most satisfied, lower values are for the less satisfied), as measured by the World Value Survey, actually decreased from 6.8 in 2006 to 4.95 in 2008, and to 4.7 during the 2006-2010 periods (Veenhoven, 2012; HDR, 2011).

South Africa's human development index, a measure of well-being in terms of education, a healthy life and decent standards of living, was at 0.619 in 2011, much the same as in 1990 (0.615), (HDR, 2011). According to the Boston Consulting Group's (BCG) new Sustainable Economic Development Assessment, South Africa has a low level of wellbeing (23.9 points) for its levels of income and development. The BCG report indicates that compared to its peers, South Africa (with a score of 49.7 out 100) has not made sufficient progress in converting wealth and GDP growth over the past five years into improvements in its citizens' wellbeing (Bisseker, 2013). Accordingly, there is a pressing need to improve citizens' living conditions. Otherwise, the potential for upheaval in South Africa, argues Bishop Tutu, (Time, 3 December 2012: 36) is "very great", and can be "very, very disturbing".

Stimulating economic growth with sustainable SME entrepreneurship is a possible way to create employ employment opportunities and to generate tax revenue, ensuring income redistribution to fund social wage and other public services. All these contribute to enhance subjective well-being and shared prosperity. Employment growth elasticity is positive for most years, and unemployment is inversely related to real GDP per capita. Legislation does not create employment. It is value-adding activities and entrepreneurial actions that generate employment opportunities. For a better quality of life, what is needed is a freer enabling environment with a delivery state that enhances the spirit of flourishing enterprise, with labour absorption, economic growth and business development. Labour absorption partly depends on the cost of labour. Hopefully, the government's introduction of a wage subsidy or the youth-employment tax incentive might lower the cost of hiring young people, and thus inducing employers to create more employment opportunities, much needed for enhanced individual prosperity.

\section{References}

Acs, Z. (2006): How is Entrepreneurship Good for Economic Growth? Innovations, Winter, pp. 97-107.

Attud, V. (2011): Black Economic Empowerment and Job Creation, in Jobs, Jobs, Jobs, ed. Nolutshungu, T. Free Market Foundation, Johannesburg, pp. 213-234.

Barker, H. (2007): The South African Labour Market: Critical Issues for Renaissance, J.L. van Schaik Publishers, Pretoria.

Bhorat, H. and Mayet, N. (2013): A Nation in Search of Jobs, in State of the Nation- South Africa 2012-2013, (eds U. Pillay, C. Hagg and F. Nyamnjoh), HSRC, Cape Town, pp. 273-304.

Bhorat, H. (2010): Unemployment in South Africa: Descriptors and Determinants, http://www.commerce.uct.ac.za/ResearchUnit/DPRU /Other, Accessed 2 February 2013.

Bisseker, C. (2012): Municipalities: On the Road to Nowhere, Financial Mail 14-19, p.44.

Bisseker, C. (2012): Labour Productivity: Self-inflicted Harm, Financial Mail, Sep 7-Sep 12, 2012, pp. 38-39.

Bisseker, C. (2013): Getting the Basics Right, Financial Mail, May 24-29, pp. 44-46.

Bisseker, C. (2013): No more Mr Nice Guy, Financial Mail, Feb 1-6, pp. 42-43. 
Budget Review (2012): Budget Speech, National Treasury, Pretoria.

Budget Review (2013): Budget Speech, National Treasury, Pretoria.

Chaitram, H. (2013): HIVIAIDS: A Perspective, Jyoti, Jan-March 2013.

Deakins, D. and Freel, M. (2012): Entrepreneurship and Small Firms, McGraw-Hill, London.

Duncan, F. (2012): SA's Small Business Problem, The South African LED Network, http://led.co.za, Accessed 7/5/12.

Field, A. (2009): Discovering Statistics Using SPSS, Sage, London.

GEM (2008): Global Entrepreneurship Monitor: 2008- South African Report, Graduate School of Business, UCT, Cape Town.

GEM (2010): Global Entrepreneurship Monitor: 2010- South African Report, Graduate School of Business, UCT, Cape Town.

Global Competitive Report 2012-2013: World Economic Forum.

Global Competitive Report 2010-2011: World Economic Forum.

Gules, N. (2012): One Step at a Time, Accounting and Business International, Vol 11: (Nov-Dec)12-14.

HDR: Human Development Report 2011, Sustainability and Equity- A Better Future for All, UNDP, New York.

Herrington, M. (2012): Africa Entrepreneurship Lacking, Business Brief, Oct/Nov, Vol 17 (5): p.14.

Herrington, M. (2011): Entrepreneurship: How an Obstacles be Overcome? in Advocates for Change, ed.

Mbeki, M. Picador Africa, Johannesburg, pp. 115-136.

Hirschowitz, R. and Orkin, M. (1997): Inequality in South Africa: Findings from the 1994 October Household Survey, in Quality of Life, Moller, V. (ed), Kluwer Publishers, London, pp. 169-182.

Holborn, L. (2011): A Lost Generation? Statement issued by the South African Institute of Labour Relations, 6 April. www.politicsweb.co.za, Accessed 7 July 2013.

Jones, G. (2013): Education Few Lessons Learnt, Financial Mail, Mar1-6, p.30.

Kingdom, G. and Knight, J. (2004): Unemployment in South Africa, World Development Review, Vole 32 (3): 391-408.

Lester, M. (2013): Good Muti for Many Taxpayers, Sunday Times, 23 June.

Loots, E. (1998): Job Creation and Economic Growth, South African Journal of Economics, Vol 66(3), pp.319-336.

Lund, T. (2012): Public Sector - Perform or else-what? Financial Mail, Aug 31- Sep 5, pp. 48-49.

Mahadea, D. and Simson, R. (2011): The Challenges of Employment Creation in South Africa, Economic Society Conference, Stellenbosch University, 5-7 September 2011, www.essa.2011.org.za.

Mahadea, D. (2013): On the Economics of Happiness: Influence of Income and Non-Income factors, South African Journal of Economics and Management Sciences, Vol 16(1): 39-51.

Mbeki, M. (2011): Advocates for Change, Picador Africa, Johannesburg.

Naude, W. (2012): Entrepreneurship in the Field of Economic Development, in Frontiers in Entrepreneurship, ed. Urban, B., Heinemann, Johannesburg, pp. 85-114.

Optima (2004): South Africa's ten years of democracy, Vol 50 (2), 36-44.

Parsons, R. (2013): Zumanomics Revisited, Jacana, Johannesburg.

Peacock, B. (2013): Taxes gobble up huge chunks of salary hikes, Sunday Times, 5 May 2013.

Perry, A. (2012): Africa Rising, Time Magazine, 3 December 2012, pp. 32-37.

Posel, D.R. and Casale, D.M. (2011): Relative Standing and Subjective well-being in South Africa, Social Indicators Research, 104(2): 195-223.

Putman, R. D. (2000): Bowling Alone, Simon and Schuster, New York.

Ramphele, M. (2012): Conversations with My Sons and Daughters, Penguin, Johannesburg.

Rautenbach, F. (2010): Labour Brokers have a Positive Impact on Job Creation, FMF Feature Article, 7 October.

Redelinghuys, J. (2013): Are they Really Free? Natal Witness, 25 June.

Saunderson-Meyer, W. (2013): ANC gets to grips with parasite control, Natal Witness, 02 March 2013.

South African Reserve Bank (2013): Quarterly Bulletins, No. 267-268, March-June, Pretoria.

South African Reserve Bank (2012): Quarterly Bulletin, No 266, December, Pretoria.

Stats SA (2013): Quarterly Labour Force Survey, May, Statistics South Africa, Pretoria.

Stats SA (2012): Quarterly Employment Statistics, December, Statistics South Africa, Pretoria.

Stats SA (2012): Census 2011, Report No. 03-01-42, Statistics South Africa, Pretoria.

Stats SA (2011): Quarterly Employment Statistics, March, Statistics South Africa, Pretoria.

Sunter, C. (2010): Foxy Futurists and How to Become One, Human and Rousseau Tafelberg, Cape Town.

The Economist (2012): Over the rainbow, October 20-26, pp. 22-24.

The Economist (2012): Education in South Africa: Still Dysfunctional, January 21, pp. 41.

The Economist (2012): South Africa's Mines: In the Pits, August 25, pp.28.

The Economist (2012): South Africa: It's not just the Mines, 8 September, pp.31-32.

Todaro, M. and Smith, S. (2012): Economic Development, Addison Wesley, London.

Urban, B. (2012): Frontiers in Entrepreneurship, Heinemann, Johannesburg.

van Niekerk, (2013): SA housing, www.info.gov.za/about social/govhousing.htm, Accessed 2 May 2013.

Veenhoven, R. (2012): Happiness in South Africa, World database of happiness, Erasmus University Rotterdam, The Netherlands, http://worlddatabaseof happiness.eur.nl, (accessed 05/05/13).

Wijnberg, C. (2013): It's time to reject the incompetence, Natal Witness, 14 May. 